PRAISE FOR PHILIP FRADKIN AND HIS WORK

"In all cultures, every religion, men and women have gone into isolation and returned with insight. Or, often equally fascinating, they have not returned. Are they lost souls hiding somewhere or victims of misadventure? They lead many to speculate about the significance of life and the significance of mystery. This book about Everett Ruess is an adventure story that builds into a mystery. So read and ponder. It kept me up nights.”

WILLIAM KITTREDGE, author of The Willow Field

"Philip Fradkin has long been one of the shrewdest interpreters of the landscapes of the American West. Here he beautifully humanizes and does justice to a haunted young man who has become a caricature. This is a gripping story told amidst the indelible, stark beauty of the canyon West."

WILliam DEVERELL, author of Whitewashed Adobe: The Rise of Los Angeles and the Remaking of Its Mexican Past and Director, Huntington-USC Institute on California and the West

"Important or famous people can sometimes disappear into legend. Innumerable young people of aspiration and talent, however-such as Everett Ruess-can vanish into a vast and devouring darkness, lured there by dreams that can never come true and demons that give no rest."

KEVIN STARR, University of Southern California and author of Coast of Dreams: California on the Edge

"The mysterious disappearance of the vagabond artist and poet Everett Ruess has fascinated historians and canyonlands buffs for nearly eighty years.

Fradkin doesn't solve the mystery of Everett's fate, but he does a meticulous job demythologizing Ruess and making him human-curious, quixotic, intense, often foolish-but very much the embodiment of the youthful loner possessed by a romanticized search for truth and beauty."

PAGE STEGNER, author of Adios Amigos: Tales of Sustenance and Purification in the American West 
"Philip Fradkin is much more than a first-rate journalist and writer. He is Trickster exposing the lies and assumptions of our culture with a fierce intellect, while at the same time creating a tenderness of heart toward all that is beautiful and just. His language is hard-edged, authentic, and clear."

TERRY TEMPEST WILLIA MS, author of Refuge and Finding Beauty in a Broken World

"Fradkin is an impassioned writer who knows his subject."

San Francisco Chronicle

"Fradkin experiences our worst public events as the very stuff of life. This lends his writing a stirring urgency."

Los Angeles Times Book Review

"With a reporter's eye for detail, Fradkin delivers in a most compelling fashion." Sacramento Bee

\section{Wallace Stegner and the American West}

"A widely published author on wilderness and the West, the Pulitzer Prizewinning Fradkin was the first environmental reporter for the Los Angeles Times. Which is to say, he's thoroughly steeped in the very landscapes and conflicts with which Stegner spent his life grappling."

HAMPTON SIDES, author of Blood and Thunder: An Epic of the American West

“Fradkin's dynamic and probing portrait of Stegner brilliantly combines literary and environmental history, and provides a fresh and telling perspective on the rampant development of the arid West."

Booklist

\section{A River No More}

"A River No More makes a statement of the utmost importance and gravity." WALlaCe STEgNer, The New Republic 
Everett Ruess 
ALSO BY PHILIP L. FRADKIN

California, the Golden Coast (1974)

A River No More (1981)

Sagebrush Country (1989)

Fallout (1989)

Wanderings of an Environmental Journalist (1993)

The Seven States of California (1995)

Magnitude 8 (1998)

Wildest Alaska (200I)

Stagecoach (2002)

The Great Earthquake and Firestorms of 1906 (2005)

Wallace Stegner and the American West (2008)

The Left Coast (2011) 


\section{Everett Ruess}

HIS SHORT LIFE, MYSTERIOUS DEATH, AND ASTONISHING AFTERLIFE

Philip L. Fradkin

甲

UNIVERSITY OF CALIFORNIA PRESS

BERKELEY LOS ANGELES LONDON 
University of California Press, one of the most distinguished university presses in the United States, enriches lives around the world by advancing scholarship in the humanities, social sciences, and natural sciences. Its activities are supported by the UC Press Foundation and by philanthropic contributions from individuals and institutions. For more information, visit www.ucpress.edu.

University of California Press

Berkeley and Los Angeles, California

University of California Press, Ltd.

London, England

(C) 201 I by Philip L. Fradkin

Library of Congress Cataloging-in-Publication Data

Fradkin, Philip L.

Everett Ruess : his short life, mysterious death, and astonishing afterlife / Philip L. Fradkin.

p. $\mathrm{cm}$.

Includes bibliographical references and index.

ISBN 978-0-520-26542-4 (cloth : alk. paper)

I. Ruess, Everett, b. I9i 4. 2. Poets, American-2oth century-Biography. 3. Explorers-Southwest, NewBiography. I. Title.

PS3535.U26Z63 20II

$811^{\prime} .52-\mathrm{dc} 22$

2011011203

[B]

Manufactured in the United States of America

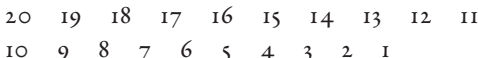

In keeping with a commitment to support environmentally responsible and sustainable printing practices, UC Press has printed this book on Rolland Enviroıoo, a 100\% post-consumer fiber paper that is FSC certified, deinked, processed chlorine-free, and manufactured with renewable biogas energy. It is acid-free and EcoLogo certified. 
For my parents, and all parents who have lost a young son or daughter 
The publisher gratefully acknowledges the generous support of Marilyn Lee and Harvey Schneider as members of the Literati Circle of the University of California Press Foundation.

The publisher also gratefully acknowledges the generous support of the Humanities Endowment Fund of the University of California Press Foundation. 
In the desert one comes in direct confrontation with the bones of existence, the bare incomprehensible absolute is-ness of being.

E DWARD ABBEY,

Confessions of a Barbarian

Nothing so augmented the interest in Ambrose Bierce as his disappearance. Obscurity is obscurity, but disappearance is fame.

CAREY MCWILLIAMS, Ambrose Bierce: A Biography

And they never found my body, boys

Or understood my mind.

DAVE ALVIN, the refrain from "Everett Ruess" 
